Original Article

\title{
Ferulic acid as major antioxidant phenolic compound of the Tetragonisca angustula honey collected in Vera Cruz - Itaparica Island, Bahia, Brazil
}

\author{
Ácido ferúlico como principal composto fenólico antioxidante do mel de Tetragonisca \\ angustula coletado em Vera Cruz - Ilha de Itaparica, Bahia, Brasil
}

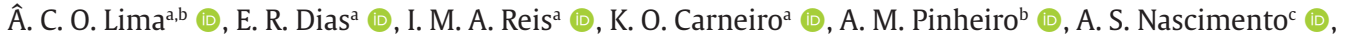

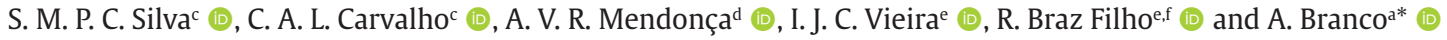 \\ anniversidade Estadual de Feira de Santana - UEFS, Laboratório de Fitoquímica, Departamento de Saúde, Feira de Santana, BA, Brasil \\ bUniversidade Federal do Recôncavo da Bahia - UFRB, Laboratório de Bioquímica e Imunologia Veterinária, Centro de Ciências Agrárias, \\ Ambientais e Biológicas, Cruz das Almas, BA, Brasil \\ 'Universidade Federal do Recôncavo da Bahia - UFRB, Núcleo de Estudos dos Insetos - INSECTA, Centro de Ciências Agrárias, Ambientais e \\ Biológicas, Cruz das Almas, BA, Brasil \\ dUniversidade Federal do Recôncavo da Bahia - UFRB, Centro de Ciências Agrárias, Ambientais e Biológicas, Cruz das Almas, BA, Brasil \\ eUniversidade Estadual do Norte Fluminense Darcy Ribeiro - UENF, Centro de Ciência e Tecnologia - CCT, Departamento de Química de \\ Produtos Naturais, Laboratório de Ciências Químicas - LCQUI, Campos dos Goytacazes, RJ, Brasil \\ Universidade Federal Rural do Rio de Janeiro - UFRRJ, Instituto de Química - IQ Departamento de Química Orgânica, Seropédica, RJ, Brasil
}

\begin{abstract}
The antioxidant activity of Tetragonisca angustula honey (TAH) and its ethanolic extract (TAEE) were investigated. The total levels of phenolic (TPC) and flavonoids (TFC) were also evaluated. The results for TPC were $19.91 \pm 0.38$ and $29.37 \pm 1.82 \mathrm{mg} \mathrm{GAE} \mathrm{g}^{-1}$ and for TFC $0.20 \pm 0.02$ and $0.14 \pm 0.01 \mathrm{mg} \mathrm{QE} \mathrm{g}^{-1}$ of TAH and TAEE, respectively. Antioxidant activities were $73.29 \pm 0.49 \%$ and $93.36 \pm 0.27 \%$ in the DPPH $\bullet$ assay and $71.73 \pm 4.07 \%$ and $97.86 \pm 0.35 \%$ in $\mathrm{ABTS}^{\bullet+}$ for TAH and TAEE, respectively. The total reducing activity was determined by the method of reducing power (PR) and iron ion (Fe III) and the results varied in PR from $151.7 \pm 25.7$ and $230.7 \pm 25.2 \mathrm{mg} \mathrm{GAE} \mathrm{L}^{-1}$, for TAH and TAEE respectively and for (Fe III) in $\mathrm{EC}_{50} 0.284$ in TAEE and 0.687 in TAH. Chemical analysis by HPLC-DAD of the ethanolic extract (TAEE) revealed the presence of ferulic acid as majority phenolic component in the extract. The ${ }^{1} \mathrm{H}$ NMR analysis confirmed this structure and showed the also presence of glucose, citric acid, succinic acid, proline and hydrocarbon derivatives. In addition, the botanical origin was also investigated and showed a multifloral characteristic, having found 19 pollen types with a botanical predominance of the Anacardiaceae family, with Tapirira pollen occurring as predominant (42.6\%) and Schinus as secondary (25.7\%). The results showed that T. angustula honey is an interesting source of antioxidant phenolic compounds due to its floral origin and can act as a protector of human health when consumed.
\end{abstract}

Keywords: antioxidant activity, botanical origin, chemical profile, stingless bee, Tetragonisca angustula.

\begin{abstract}
Resumo
A atividade antioxidante do mel de Tetragonisca angustula (TAH) e seu extrato etanólico (TAEE) foram investigados. Os níveis totais de fenólicos (TPC) e flavonóides (TFC) também foram avaliados. Os resultados para TPC foram 19,91 \pm 0,38 e 29,37 $\pm 1,82 \mathrm{mg} \mathrm{GAE} \mathrm{g}^{-1}$ e para TFC 0,20 $\pm 0,02$ e 0,14 $\pm 0,01 \mathrm{mg} \mathrm{QE} \mathrm{g}^{-1}$ de TAH e TAEE, respectivamente. As atividades antioxidantes foram 73,29 $\pm 0,49 \%$ e 93,36 $\pm 0,27 \%$ no ensaio DPPH $\bullet$ e 71,73 $\pm 4,07 \%$ e $97,86 \pm 0,35 \%$ no $\mathrm{ABTS}^{\bullet+}$ para TAH e TAEE, respectivamente. A atividade redutora total foi determinada pelo método de poder redutor (PR) e íon ferrico (Fe III) e os resultados variaram em PR de 151,7 $\pm 25,7$ e 230,7 $\pm 25,2$ mg GAE L'${ }^{-1}$, para TAH e TAEE respectivamente e para (Fe III) em $\mathrm{EC}_{50} 0,284$ em TAEE e 0,687 em TAH. A análise química por HPLCDAD do extrato etanólico (TAEE) revelou a presença de ácido ferúlico como componente majoritário no extrato. A análise de $\mathrm{RMN}{ }^{1} \mathrm{H}$ confirmou esta estrutura e mostrou a presença de glicose, ácido cítrico, ácido succínico, prolina e derivados de hidrocarbonetos no TAEE. Além disso, a origem botânica também foi investigada e apresentou característica multifloral, tendo encontrado 19 tipos polínicos com predomínio botânico da família Anacardiaceae, sendo o pólen Tapirira predominante (42,6\%) e o Schinus secundário (25,7\%). Os resultados mostraram que o mel de T. angustula é uma interessante fonte de compostos fenólicos antioxidantes devido à sua origem floral e pode atuar como protetor da saúde humana quando consumido.
\end{abstract}

Palavras-chave: atividade antioxidante, origem botânica, perfil químico, abelha sem ferrão, Tetragonisca angustula.

*e-mail: branco@uefs.br

Received: June 24, 2021 - Accepted: September 14, 2021

This is an Open Access article distributed under the terms of the Creative Commons Attribution License, which permits unrestricted use, distribution, and reproduction in any medium, provided the original work is properly cited. 


\section{Introduction}

Jatai bee (Tetragonisca angustula) is an easily adaptable species of stingless bee that can be raised both in rural and urban areas (Grüter et al., 2011). Although they produce honey in a small amount, they provide a product that differs from Apis mellifera L. honey, especially in the peculiar flavor and aroma, what causes its prices to rise in the market. Honey produced by meliponini is a valuable product that has very different characteristics, being used by the old consumption tradition mainly for medicinal purposes (Almeida-Muradian et al., 2013). The honey is a natural source of health due to its therapeutic qualities, antimicrobial and anti-inflammatory activities, antioxidant properties and prebiotics (Sgariglia et al., 2010; Nishio et al., 2016).

Honey is the result of nectar and saccharin exudation of plants, collected, modified and stored by honey bees. It has a complex mixture composed mainly of water, carbohydrates, fatty acids, proteins, amino acids, vitamins, minerals, natural products and phenolic compounds. These phenolic compounds are largely responsible for the antioxidant activity of honey and can act as free radical reducing agents or as chelators of pro-oxidant metal ions, but they can also modulate several intracellular pathways (Wang and Lin, 2000; Alvarez-Suarez et al., 2012). Natural antioxidants are effective in reducing the risk of cardiovascular, metabolic, visual, immunological diseases and several other acute and chronic inflammatory processes (Rao et al., 2016). Phenolic compounds, comprising phenolic acids and flavonoids, are also considered as potential indicators of botanical origin (Alvarez-Suarez et al., 2012). Thus, honeys produced by distinct bee species or collected from different locations have different active compounds and, consequently, differ as for their biological properties.

Chemical and biological studies on Tetragonisca angustula honey are scarce in the literature, and it is known that these products have differences, especially in the phenolic profile, when compared to honey produced by Apis bees (Rodríguez-Malaver et al., 2009, Silva et al., 2013b). Recently, we described the identification of four hydroxycinnamic acid-spermidine amides from Tetragonisca angustula honey as anti-Neospora caninum (Lima et al., 2021). The aim of this study was to investigate the antioxidant activity and chemical profile of Tetragonisca angustula honey and its extract, as well as to identify its botanical origin.

\section{Materials and Methods}

\subsection{Obtaining of the crude extract and fractions}

The ethanol extract (TAEE) of the Tetragonisca angustula honey collected in the municipality of Vera Cruz on Itaparica Island (state of Bahia, NE Brazil) (12둑' 32 ”S x 38 $36^{\prime}$ '16”W), registered with SISGEN under №. AA64E09, was prepared using Ethanol PA (1:3) according to the methodology of Siess et al. (1996), modified by Trusheva et al. (2007). Three hundred grams of TAH was added with $900 \mathrm{~mL}$ of ethanol and kept at room temperature, protected from light for a period of four days, when finally, the solvent was removed, pouring by hand.

\subsection{Determination of antioxidant components}

\subsection{Total phenolic content (TPC)}

Concentration of total phenolics was determined with the Folin-Ciocalteau phenol reagent (Synth ${ }^{\circledR}$ ) according to the methodology described by Singleton et al. (1999). Aliquots (2.5 g) of TAH and TAEE were diluted in $25 \mathrm{~mL}$ distilled water $(100 \mathrm{mg} / \mathrm{mL}$ concentration $)$ of stock solution, in $0.5 \mathrm{ml}$ of this solution $2.5 \mathrm{ml}$ of $0.2 \mathrm{~N}$ Folin-Ciocalteu reagent was added for $5 \mathrm{~min}$. Subsequently, they were added with $2 \mathrm{~mL}$ of sodium carbonate $\left(\mathrm{Na}_{2} \mathrm{CO}_{3}\right)$ solution at $7.5 \%$. After the reaction mixture incubated for 1 hour at room temperature and protected from light, absorbance was measured using a WPA Lightwave II spectrophotometer (Biochrom) at $760 \mathrm{~nm}$. The values were interpolated on a calibration curve made with gallic acid (Sigma $\left.{ }^{\circledR}\right)$. The results were expressed in mg equivalent of gallic acid per gram ( $\mathrm{mg} \mathrm{GAE} \mathrm{g}^{-1}$ ). The blank consisted of a solution of $0.5 \mathrm{~mL}$ of ethanol together with $2.5 \mathrm{~mL}$ of Folin-Ciocalteu reagent and $2.0 \mathrm{~mL}$ of sodium carbonate solution.

\subsection{Total flavonoid content (TFC)}

The total flavonoid content was determined by the colorimetric reaction with aluminum trichloride (Dinamic) performed according to the method described by Woisky and Salatino (1998). A 2.5-g aliquot of TAH and TAEE samples was diluted in distilled water ( $100 \mathrm{mg} / \mathrm{mL}$ concentration) and mixed $2.5 \mathrm{~mL}$ with $2.5 \mathrm{~mL}$ of a methanolic solution $(2 \mathrm{~g} / 100 \mathrm{~mL})$ of aluminum trichloride $\left(\mathrm{AlCl}_{3}\right)$. The reading was performed on a spectrophotometer (Biochrom) at $420 \mathrm{~nm}$ after 1 hour at room temperature and in the dark. The absorbance values were interpolated on a standard quercetin curve $\left(\right.$ Sigma $\left.^{\circledR}\right)$. The results were then expressed in mg equivalent of quercetin per gram $\left(\mathrm{mg} \mathrm{QE} \mathrm{g}^{-1}\right)$. The blank contained a solution of $2.5 \mathrm{~mL}$ of ethanol together with $2.5 \mathrm{~mL}$ of $\mathrm{AlCl}_{3}$ reagent without methanol.

\subsection{Evaluation of antioxidant properties}

\subsubsection{Free radical capture activity}

The antioxidant activity of TAH and TAEE was determined by the methods of $\mathrm{DPPH} \bullet$ (1,1-diphenyl-2-picrilhidrazil) according to a procedure described by Meda et al. (2005) and 2,2'-azino-bis (3-ethylbenzothiazoline-6-sulfonic) $\left(\right.$ ABTS $^{\circ+}$ ) based on the methodology described by Lee et al. (2017), with some modifications. The samples were initially diluted to a concentration of $100 \mathrm{mg} / \mathrm{mL}$ in distilled water, to prepare the stock solution.

For the DPPH ${ }^{\bullet}$ assay, $0.3 \mathrm{~mL}$ of the stock solution was added to $2.7 \mathrm{~mL}$ of $\mathrm{DPPH} \cdot 0.024 \%$ solution diluted in methanol. Distilled water $(0.3 \mathrm{~mL})$ in $2.7 \mathrm{~mL}^{\circ} \mathrm{DPPH}^{\bullet}$ solution (Sigma ${ }^{\circledR}$ ) was used, serving as the blank sample. The mixtures were left for $1 \mathrm{~h}$ at room temperature in the dark and the absorbance was measured in an Evolution 220 UV-Vis spectrophotometer (Thermo Scientific) at $517 \mathrm{~nm}$. Measurements were performed in triplicate. The reading of the optical density of the samples was correlated with the standard $\mathrm{DPPH} \bullet$ control, establishing 
the percentage of discoloration of the $\mathrm{DPPH}{ }^{\bullet}$ radical according to Equation 1:

$$
\% \mathrm{RSA}=\frac{[(\mathrm{ADPPH}-\mathrm{As})]}{\mathrm{ADPPH}} \times 100
$$

Where: $\mathrm{ADPPH}=$ Absorbance $\mathrm{DPPH}$ and As = Sample Absorbance.

For the ABTS ${ }^{\bullet+}$ assay a stock solution was prepared by dissolving ABTS $^{\bullet+}\left(\right.$ Sigma $\left.^{\circledR}\right)(7 \mathrm{mM})$ and potassium persulfate (Dynamic) $(2.45 \mathrm{mM}$ ) in ultrapure water and left protected from light at room temperature for $16 \mathrm{~h}$. The ABTS ${ }^{\bullet+}$ solution was diluted with ethanol to reach an absorbance value of 1.0 (Di Castillo et al., 2015) at $753 \mathrm{~nm}$ (Dong et al., 2015) using a spectrophotometer (Thermo Scientific). Two hundred microliters of aqueous solutions of TAH and TAEE $(100 \mathrm{mg} / \mathrm{mL})$ were mixed with $2.8 \mathrm{~mL}$ of ABTS ${ }^{\bullet+}$ diluted solution, the mixture was vortexed and left in the dark at room temperature for 30 minutes. The blank sample consisted of distilled water $(200 \mu \mathrm{L})$ and ethanol $(2.8 \mathrm{~mL})$. The results were expressed as the radical scavenging capacity (\% RSA) using Equation 1 . The control sample was composed of ABTS ${ }^{\bullet+}$ diluted solution and $200 \mu \mathrm{L}$ of distilled water.

\subsubsection{Total reducing activity}

The total reducing activity of TAH and TAEE was evaluated using two methodologies: the modified FolinCiocalteu (PR) method as described by Berker et al. (2013), with some modifications, and the reducing power of the ferric ion (Fe III) determined by the method described in the literature by Berker et al. (2007).

The Folin-Ciocalteu reagent $\left(\right.$ Synth $^{\circledR}$ ) was diluted in isobutanol (Dynamic) at a retention of 1: $2(\mathrm{v} / \mathrm{v})$ and an aliquot $(60 \mu \mathrm{L})$ was mixed with $40 \mu \mathrm{L}$ of stock solution of TAH and TAEE, followed by adding $700 \mu \mathrm{L}$ of sodium hydroxide solution $(0.1 \mathrm{M})$ and $1.200 \mu \mathrm{L}$ of distilled water. The tubes were vortexed and allowed to react in the dark, at room temperature, for $20 \mathrm{~min}$. Ethanolic gallic acid solution(Sigma ${ }^{\circledR}$ ) was used as a standard $(100-600 \mu \mathrm{g} / \mathrm{mL})$. The absorbance was read at $665 \mathrm{~nm}$ using a UV-Vis spectrophotometer (Thermo Scientific) and the results were interpolated in a standard curve of gallic acid and the data expressed in mg equivalent of gallic acid per liter ( $\mathrm{mg} \mathrm{GAE} \mathrm{L}^{-1}$ ).

For the test of reducing power of the ferric ion (Fe III), in test tubes, $1 \mathrm{~mL}$ of the stock solution of each sample was added in $2.5 \mathrm{~mL}$ of $0.2 \mathrm{M}$ phosphate buffer ( $\mathrm{pH} 6.6$ ) and $2.5 \mathrm{~mL}$ of potassium ferricyanide (Dynamic) at $1 \%$. The mixture was incubated in a water bath at $50{ }^{\circ} \mathrm{C}$ for 20 minutes. Subsequently, the tubes were kept at room temperature. $2.5 \mathrm{~mL}$ of $10 \%$ trichloroacetic acid (TCA) (Dynamic) was added and the mixture was stirred vigorously. Then, $2.5 \mathrm{~mL}$ of distilled water and $0.5 \mathrm{~mL}$ of $0.1 \%$ iron chloride (Dynamic) were added. The mixture was kept for 2 minutes. Absorbance was measured with a spectrophotometer (Thermo Scientific) at $700 \mathrm{~nm}$. The concentration value that induced 50\% inhibition of free radicals $\left(\mathrm{EC}_{50}\right)$ was calculated from the absorbance graph and measured in triplicate, depending on the concentrations of honey and extract $[0.25 ; 0.5 ; 1.0$; $1.5 ; 2.0 ; 2.5 ; 3.0]$.

\subsection{Determination of chemical properties}

\subsubsection{NMR analysis}

${ }^{1} \mathrm{H}$ NMR spectra were measured on a Bruker Advance 500 spectrometer operating at $500 \mathrm{MHz}$ for ${ }^{1} \mathrm{H}$ and $125 \mathrm{MHz}$ for ${ }^{13} \mathrm{C}$, using deuterated chloroform $\left(\mathrm{CDCl}_{3}\right)$ as solvent (approximately $10-15 \mathrm{mg}$ of samples were dissolved in $0.5 \mathrm{~mL}$ of solvent and transferred into a 5-mm NMR tube), internal lock and TMS as internal reference.

\subsubsection{HPLC-DAD analysis}

The extract (10 mg) was mixed with methanol until completely fluid, filtered on a $0.22-\mu \mathrm{m}$ PTFE filter and placed in a vial for injection in a high-performance liquid chromatography apparatus with ultraviolet diode array detector (UV/DAD). The HPLC analysis was used with mobile phase reagents containing a gradient at $0.1 \%$ acetic acid $\left(\mathrm{CH}_{3} \mathrm{COOH}\right)$ in $\mathrm{H}_{2} \mathrm{O}(\mathrm{A})$ and methanol (B) in the following elutions: $0-30 \mathrm{~min}, 100-0 \% \mathrm{~B} ; 31-37 \mathrm{~min}, 0-100 \% \mathrm{~B}$; 38-40 min, 0-100\% B. A DAD semiprep system was used for the isolation of pure compounds and comprised a LiChrospher ${ }^{\circledR} 100$ RP-18 column ( $\left.250 \mathrm{~mm} \times 4 \mathrm{~mm} \times 5 \mu \mathrm{m}\right)$ with a $10-\mu \mathrm{L} / \mathrm{min}$ flow rate and column temperature adjusted to $30^{\circ} \mathrm{C}$, with a binary gradient phase of the reagents under the same conditions. Suggestion for the identification of phenolic compounds was based on the retention times of authentic markers acquired in Sigma Aldrich $^{\circledR}$ as well as evaluation of the UV-Vis spectrum.

\subsection{Botanical origin}

\subsubsection{Melissopalynological analysis}

The botanical origin of TAH was confirmed through melissopalinological analysis (Von der Ohe et al., 2004). TAH was submitted to the Erdtman acetolysis process (Erdtman, 1960) and the resulting pellet was mounted on slides with glycerinated gelatin for the identification and counting of the pollen grains that make up the pollen spectrum of the sample. The pollen grains were characterized using an Olympus ${ }^{\circledR}$ optical microscope (CX41) and the images were captured with an Olympus ${ }^{\circledR}$ digital camera (Evolt E-330) attached to the 100x objective. Pollen types were identified in double blind, using specialized literature (Online Palynological Database, 2018) and through consultation on the database and images of the Palinoteca of the Federal University of Reconcavo da Bahia. The frequency class of the pollen types was determined following the classification proposed by Louveaux et al. (1978).

\subsection{Statistical analysis}

The descriptive statistics of mean and standard deviation were determined for the variables TPC, TFC, DPPH ${ }^{\bullet}, \mathrm{ABTS}^{\bullet+}$ and PR and calculated by Student's t test at $1 \%$ significance. The normality of the data was verified by Shapiro-Wilks. Pearson's linear correlation coefficients, whose significance was calculated by the Student's t test under $5 \%$ probability. The analyzes were performed using the statistical program R (R Core Team, 2020). 


\section{Results and Discussion}

\subsection{Antioxidant properties}

Due to the presence of phenolic compounds found in the sample and the antioxidant potential of these compounds was initially determined, the total phenolic contents (TPC) and it was observed that TAH and TAEE showed $19.91 \pm 0.38$ and $29.37 \pm 1.82 \mathrm{mg} \mathrm{GAEg}^{-1}$. Silva et al. (2013b) studying Jandaira honey (M. subnitida) collected in the Atlantic Forest region, reported values of total phenolic content of 1.2 to $1.3 \mathrm{mg} \mathrm{GAE} \mathrm{g}^{-1}$ in pure honey and 125.90 to $391.9 \mathrm{mg} \mathrm{GAE} \mathrm{g}^{-1}$ in the ethanolic fraction, values of the extract higher than that found in this study. Our results are within the average of that reported in the methanolic extract of stingless bees from the Brazilian Amazon region, with values from 17 to $66 \mathrm{mg} \mathrm{GAE} \mathrm{g}^{-1}$ (Silva et al., 2013a).

The values of total flavonoid content (TFC) found in this study for TAH and TAEE were $0.20 \pm 0.02$ and $0.14 \pm 0.01 \mathrm{mg}$ $\mathrm{QE} \mathrm{g}^{-1}$, respectively. Similar values of total flavonoid content have been reported for Trigona carbonaria honey $(0.10 \mathrm{mg}$ $\mathrm{QEg}^{-1}$ ) from Australia (Oddo et al., 2008), from different sources: sunflower honey (0.12-0.15 $\left.\mathrm{mg} \mathrm{QE} \mathrm{g}^{-1}\right)$, melate (0.05-0.28 $\left.\mathrm{mg} \mathrm{QE} \mathrm{g}^{-1}\right)$, Acacia (0.01-0.02 $\left.\mathrm{mg} \mathrm{QE} \mathrm{g}^{-1}\right)$ and Tilia honey (0.05-0, $07 \mathrm{mg} \mathrm{QE} \mathrm{g}^{-1}$ ) (Al et al., 2009).

Since phenolics and flavonoids are described in the literature as having antioxidant activity, we determined the antioxidant activity of this sample and the values found to inhibit antioxidant activity at a concentration of $100 \mathrm{mg} / \mathrm{mL}$ showed that the capture of $\mathrm{DPPH} \bullet$ and ABTS $^{\bullet+}$ radicals by TAH were $73.29 \pm 0.49 \%$ and $71.73 \pm$ $4.70 \%$, respectively. On the other hand, TAEE captured $93.36 \pm 0.27 \%$ and $97.86 \pm 0.35 \%$ of the radicals $\mathrm{DPPH}^{\bullet}$ and $\mathrm{ABTS}^{\bullet}$, respectively. The percentages of radical scavenging obtained for TAH in this study were similar to results reported in the literature on honey from several countries (Almeida et al., 2016). Thus, natural honey has a very broad antioxidant activity, ranging from 23.89 to 100\% inhibition (Dżugan et al., 2017).

Variations in the profile of phenolic compounds can be attributed to the botanical characteristics of honey and the chemical capacity it has to capture the analyzed radicals (Atoui et al., 2005). In honey, the antioxidant capacity may be the result of a combination of several compounds, including phenolics, peptides, organic acids, enzymes, minerals, products of the Maillard reaction and other minor compounds (Sant'ana et al., 2012).

The reducing power, which is an index of antioxidant activity, was evaluated using the Folin-Ciocalteu reagent and the reducing capacity of the ferric ion. The reducing power of TAH and TAEE using the Folin-Ciocalteu reagent was $156.63 \pm 20.06$ and $230.66 \pm 25.23 \mathrm{mg} \mathrm{GAE} \mathrm{L}^{-1}$, respectively. The reducing power of Fe (III) was influenced by the concentration of honey, in all tested concentrations $[0.25 ; 0.5 ; 1.0 ; 1.5 ; 2.0 ; 2.5 ; 3.0]$, it was indicated that TAEE had a significant reducing power $\left(\mathrm{EC}_{50} 0.284\right)$ and showed better activity than TAH $\left(\mathrm{EC}_{50} 0.687\right)$, due to the extraction process, it was expected that the extract would show results superior to raw honey.

According to Table 1, most of the correlations were not significant between the parameters evaluated in honey and extract. However, four significant correlations were observed, two positive and two negative. The significant positive correlations $\mathrm{r}=0.70\left({ }^{*} \mathrm{p}=0.024\right)$ were between TPC/TFC of T. angustula honey, characteristics observed by $\mathrm{Al}$ et al. (2009) who reported a correlation similar to that found in this study, between total phenolics and total flavonoids $(r=0.84)$, as well as a significant correlation between RSA and total phenolic content $(r=0.94)$, as well as between RSA and total flavonoids $(r=0.83)$.

Another positive correlation $\mathrm{r}=0.64\left({ }^{*} \mathrm{p}=0.047\right)$ between $\mathrm{PR} / \mathrm{DPPH} \mathrm{H}^{\bullet}$ of TAEE was found in this study, which can determine a high antioxidant activity by these methods related to TAEE. Chua et al. (2013) mentioned that both phenolic compounds and honey flavonoids play important roles in antioxidant activity. In the honey samples analyzed by these authors, the flavonoid content was correlated with $\mathrm{DPPH}^{\bullet}(r=0.9276)$ and with the antioxidant power of iron reduction $(r=0.9910)$; while the total phenolic content was only correlated with the iron reducing power $(r=0.9033)$.

The significant negative correlations found indicate an inversely proportional relationship $\mathrm{r}=-0.64\left({ }^{*} \mathrm{p}=0.048\right)$ observed between PR/TFC both evaluated in the extract and $\mathrm{r}=-0.75\left({ }^{*} \mathrm{p}=0.012\right)$ between the PR of the TAEE /TFC of the TAH. The inversely proportional correlation related to TFC and PR may be due to the fact that flavonoids can chelate metals preventing their iron reduction activity (Wang and Lin, 2000).

The reducing power (PR) correlated significantly with TFC and DPPH ${ }^{\bullet}$, as TAH and TAEE interact with Fe, justifies the high efficiency of TAEE as an agent that can protect against oxidative damage induced by iron (PardoAndreu et al., 2006). Li et al. (2009) reported the existence of a similar linear correlation between the reducing power and the total phenolic content and Tuksitha et al. (2018), suggested that stingless honeys have useful amounts of phenolic compounds and flavonoids that are capable of acting as natural antioxidants.

Corroborating what was expected; some substances that make up the honey of Tetragonisca angustula are potentially responsible for its biological activity and can act simultaneously or in isolation. Considering the beneficial action of phenolic compounds for human health in the treatment of cardiovascular and chronic diseases (Moniruzzaman et al., 2014; Oršolić and Car, 2014), the use of $T$. angustula honey in the diet is a promising alternative as a source of phenolic compounds with antioxidant potential. Phenolic substances are important antioxidants, related to the stabilization of free radicals, acting as reducing agents, inhibitors of enzymes, as metal chelators, in addition to participating in the signaling pathway (Wang and Lin, 2000).

Ayna et al. (2020) demonstrated that the use of antioxidants as nutritional supplements and, in particular, caffeic, ferulic and quercetin acids, protected cells and reduced apoptosis-induced cell death in the immune system, liver, heart and kidneys.

\subsection{Chemical properties}

Honey is a very complex matrix with very specific physical-defined properties and this complexity makes the analysis of honey difficult in terms of its different properties. 
Table 1. Pearson's correlation matrix of phenolic and flavonoid contents (TPC, TFC) and antioxidant activity (DPPH•, ABTS ${ }^{\bullet+}$ and PR) of Tetragonisca angustula honey (TAH) and ethanolic extract (TAEE).

\begin{tabular}{|c|c|c|c|c|c|c|c|c|c|c|c|}
\hline \multirow{2}{*}{\multicolumn{2}{|c|}{ TPC }} & \multicolumn{5}{|c|}{ TAH } & \multicolumn{5}{|c|}{ TAEE } \\
\hline & & \multirow{2}{*}{$\begin{array}{c}\text { TFC } \\
1\end{array}$} & \multirow{2}{*}{ 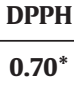 } & \multirow{2}{*}{$\frac{\text { ABTS }}{0.31^{\mathrm{ns}}}$} & \multirow{2}{*}{$\begin{array}{c}\text { PR } \\
-0.31^{\mathrm{ns}}\end{array}$} & \multirow{2}{*}{ 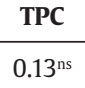 } & \multirow{2}{*}{$\begin{array}{c}\text { TFC } \\
0.15^{\text {ns }}\end{array}$} & \multirow{2}{*}{$\frac{\text { DPPH }}{0.03^{\text {ns }}}$} & \multirow{2}{*}{$\begin{array}{c}\text { ABTS } \\
-0.37^{\mathrm{ns}}\end{array}$} & \multicolumn{2}{|l|}{ PR } \\
\hline ТАН & TPC & & & & & & & & & $-0.55^{\mathrm{ns}}$ & $-0.47^{n s}$ \\
\hline & TFC & & 1 & $0.40^{\text {ns }}$ & $-0.22^{\mathrm{ns}}$ & $-0.21^{\mathrm{ns}}$ & $-0.18^{\mathrm{ns}}$ & $0.20^{\mathrm{n}} \mathrm{S}$ & $-0.41^{\mathrm{ns}}$ & $-0.44^{\mathrm{ns}}$ & $-0.75^{*}$ \\
\hline & DPPH & & & 1 & $0.20^{\mathrm{ns}}$ & $0.57^{\text {ns }}$ & $-0.54^{\mathrm{ns}}$ & $0.02^{\text {ns }}$ & $0.38^{\mathrm{ns}}$ & $-0.32^{\mathrm{ns}}$ & $-0.17^{\mathrm{ns}}$ \\
\hline & ABTS & & & & 1 & $0.53^{\text {ns }}$ & $-0.13^{n s}$ & $0.03^{\text {ns }}$ & $0.01^{\mathrm{ns}}$ & $0.49^{\text {ns }}$ & $-0.08^{\mathrm{ns}}$ \\
\hline & PR & & & & & 1 & $-0.06^{\mathrm{ns}}$ & $-0.09^{\mathrm{ns}}$ & $0.45^{\mathrm{ns}}$ & $-0.21^{\mathrm{ns}}$ & $0.22^{\mathrm{ns}}$ \\
\hline \multirow[t]{5}{*}{ TAEE } & TPC & & & & & & 1 & $-0.33^{\text {ns }}$ & $-0.43^{n s}$ & $0.28^{\text {ns }}$ & $0.06^{\mathrm{ns}}$ \\
\hline & TFC & & & & & & & 1 & $-0.22^{\mathrm{ns}}$ & $-0.12^{\mathrm{ns}}$ & $-0.64^{*}$ \\
\hline & DPPH & & & & & & & & 1 & $-0.33^{\mathrm{ns}}$ & $0.64^{*}$ \\
\hline & ABTS & & & & & & & & & 1 & $0.04^{\mathrm{ns}}$ \\
\hline & PR & & & & & & & & & & 1 \\
\hline
\end{tabular}

${ }^{*}$ significant at $5 \%$ probability by $\mathrm{t}$ test; ${ }^{\mathrm{ns}}$ not significant at $5 \%$ probability.

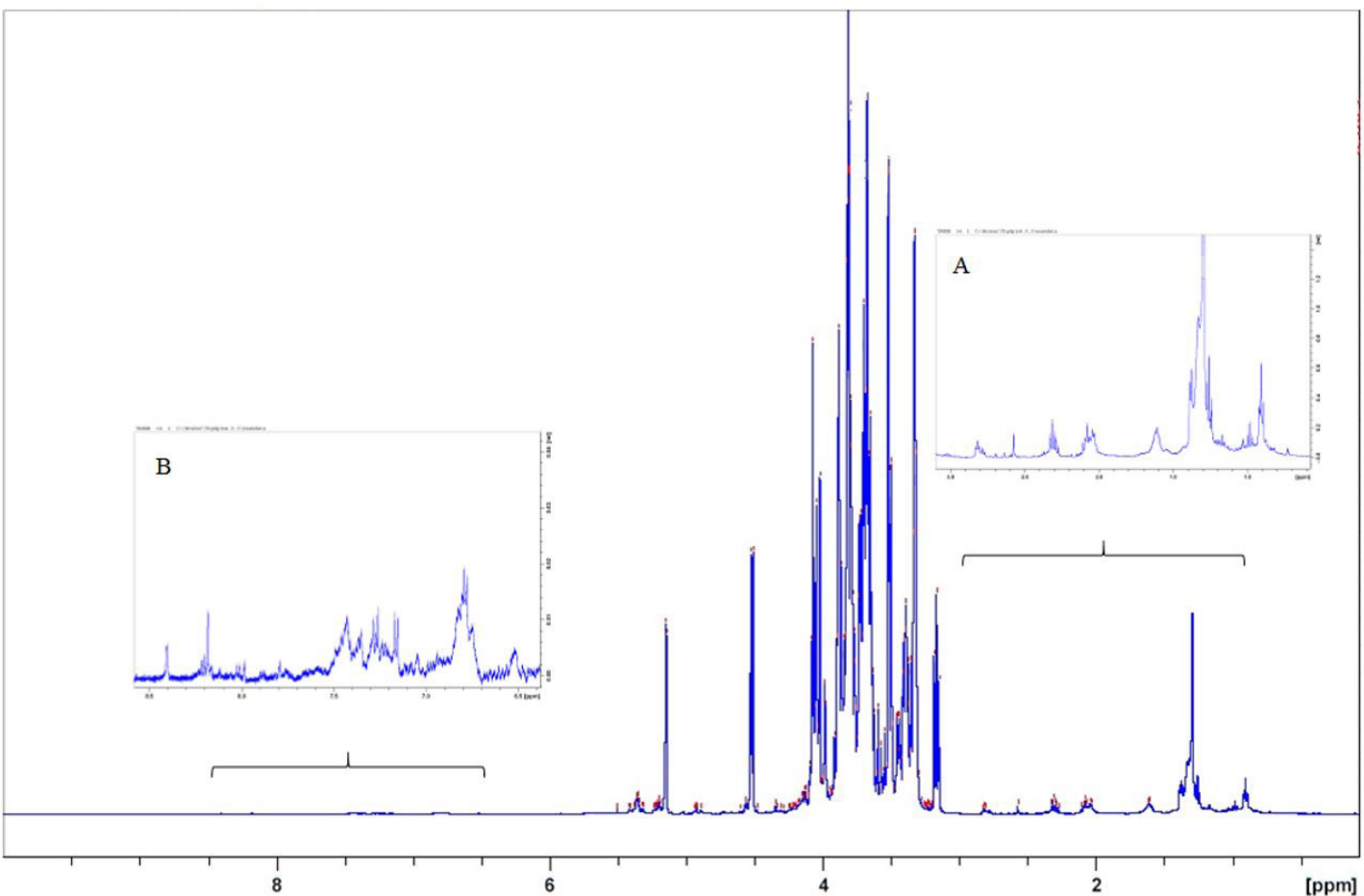

Figure 1. ${ }^{1} \mathrm{H}-\mathrm{NMR}$ spectrum of Tetragonisca angustula honey. The extensions are focused on spectral regions containing signals of lesser intensity: the smallest and most discriminating information. A. aliphatic hydrogen; B. aromatic region.

The ${ }^{1} \mathrm{H}$ NMR spectra (see Figure 1 ) of TAEE showed three characteristic absorption regions of honey: aliphatic hydrogen $(0.8$ - $3.0 \mathrm{ppm})$ (see Figure 1A), carbohydrate (3.0 - 5.6 ppm) and aromatic (6.5 - 8.5 ppm) (see Figure 1B). Individual signs were assigned based on data from the literature (Kosaka et al., 2015; Kortesniemi et al., 2016; Salgueiro et al., 2016; Consonni et al., 2019). The signal of citric acid, succinic acid, proline and hydrocarbon derivatives were observed in the aliphatic region (Spiteri et al., 2015), while the aromatic hydrogen signal confirms the presence of phenolic acid and flavonoids in the honey investigated here.

There are studies that show that the content of protons in aromatic groups is positively related to the antioxidant capacity of food products (Polak and Bartoszek, 2015; Bartoszek et al., 2017). This fact may suggest that these 
compounds found in the extract are mainly responsible for the antioxidant properties of this honey.

Then, the samples were analyzed by HPLC-DAD, below the chromatogram obtained at the wavelength of $360 \mathrm{~nm}$ (see Figure 2) and as shown in Table 2 shows the class of compounds characterized in the TAEE chromatogram.

The class of major compounds featured in the TAEE's $360 \mathrm{~nm}$ chromatogram demonstrated a characteristic region of phenolic acids and flavonols. As can be seen in Figure 2 and Table 2, the HPLC-DAD analysis of TAEE in comparison with authentic standards suggests the major peak 5 [( $\lambda \max ) 299$ (sh) 323 and $211 \mathrm{~nm}$ ] as ferulic acid.
Ferulic acid is a phenolic acid widely distributed in the plant kingdom. It presents a wide range of potential therapeutic effects useful in the treatment of cancer, diabetes, pulmonary and cardiovascular diseases, as well as hepatic, neuro and photoprotective effects and inflammatory antimicrobial and anti-inflammatory activities (Kampa et al., 2004; Bobany et al., 2010; Paiva et al., 2013).

Phenolic compounds, aromatic acids, alcohols, terpenes and sugars have been observed in other studies with stingless honey in Brazil (Silva et al., 2013a; Silva et al., 2013b; Costa et al., 2018; Ciappini, 2019). In samples of stingless

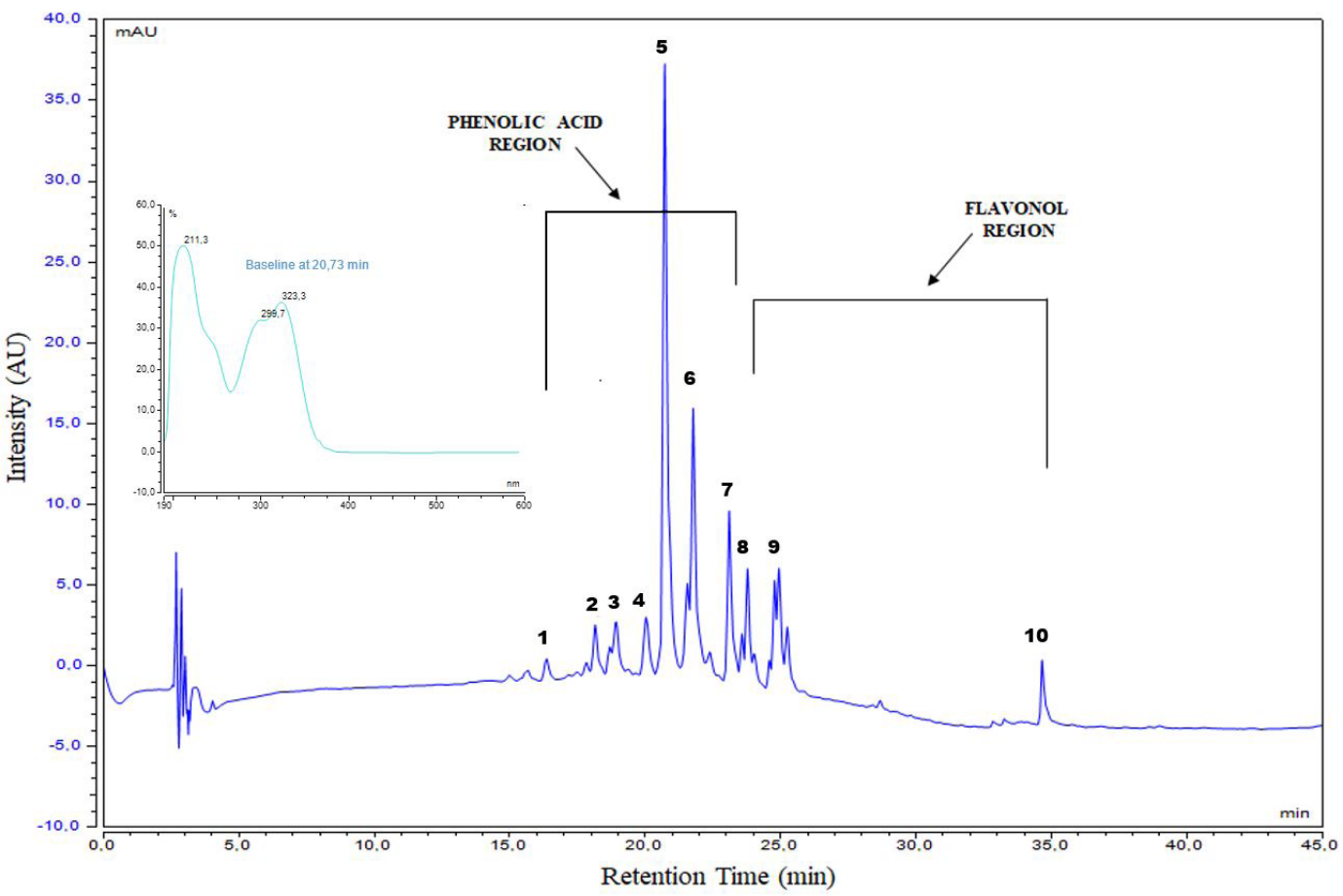

Figure 2. The chromatogram obtained by HPLC-DAD from TAEE at a wavelength of $360 \mathrm{~nm}$. Characteristic region of phenolic acids and flavonols. The peak 5 was identified as ferulic acid, which was also confirmed by retention time comparison with a authentic standard.

Table 2. Characterization of phenolic compound classes by means of UV spectrum of peaks present in chromatograms of TAEE.

\begin{tabular}{cccc}
\hline Peak & Tr $(\mathbf{m i n})$. & UV & Class of compounds \\
\hline 1 & 14.05 & $196.0 / 285.4$ & Phenolic acid \\
2 & 18.18 & $196.9 / 218.4 / 323.3$ & Derived from cinnamic acid \\
3 & 18.86 & $196.7 / 298 / 315.9$ & Derived from cinnamic acid \\
4 & 19.45 & $196.8 / 297.4 / 313$ & Derived from cinnamic acid \\
5 & 20.73 & $211.3 / 299.7(s h) 323.3$ & Ferulic acid \\
6 & 21.90 & $201.5 / 263.1 / 320.8$ & Derived from cinnamic acid \\
7 & 23.13 & $199.6 / 300.8$ & Derived from cinnamic acid \\
8 & 23.88 & $199.1 / 279.4 / 375.4$ & Flavonol \\
9 & 25.05 & $200.5 / 276.5 / 378.6$ & Flavonol \\
10 & 34.70 & $201.6 / 262.7 / 365.5$ & Flavonol
\end{tabular}

TAEE = Tetragonisca angustula honey ethanolic extract; $\operatorname{Tr}(\min )=$. retention time in minutes; $\mathrm{UV}=$ ultraviolet. 
honey from Australia, Portugal and Malaysia, ferulic, gallic, caffeic, chlorogenic, vanillic and rosmarinic acids were found, as well as myricetin, quercetin and kaempferol (Tomas-Barberan et al., 2001; Moniruzzaman et al., 2014). A wide variety of chemical constituents in small amounts are part of honey and many are known for their antioxidant properties that include phenolic acids and flavonoids.

\subsection{Botanical origin}

The sample collected in the municipality of Vera Cruz, Bahia, was evaluated for botanical origin through pollen analysis compared to the literature, having identified 19 pollen types distributed in 14 botanical families (as shown in Table 3), with the pollen type Tapirira occurring as pollen predominant (42.60\%) and Schinus as secondary pollen (25.70\%). These results confirm the influence of the diversity of flora in the Atlantic Forest region on the composition of honey (see Figure 3). The pollen types Borreria, Eucalyptus, Serjania, Tapirira and Waltheria represent genera that include botanical species considered nectariferous and important for the production of honey (Silva et al., 2013b; Nascimento et al., 2015). Predominant pollen from the Anacardiaceae family was found in Trigona honey (Frieseomelitta), Nigra paupera and Scaptotrigona ochrotica. Corroborating our results, the pollen type Tapirira guianensis was identified in samples of T. angustula in the north of the state of Pará (Novais et al., 2014) and in the northeast of Brazil; and Schinus was also considered frequent in the Northeast of Brazil (Novais et al., 2013).

The species of the Anacardiaceae family have shown promise in the search for bioactive compounds, involving the largest number of investigations, mainly regarding their metabolic constituents. Among these constituents are phenolic and catecholic compounds, or the mixture of them, called phenolic lipids, or terpenes and flavonoids, among other metabolites (Correia et al., 2006). The popular medicinal use aroused interest in the study of the chemical composition and biological activity of its extracts and metabolites and in the study of many species of these genera it was possible to detect flavonoids (mainly biflavonoids), terpenes, steroids, xanthones, phenolic lipids and derivatives (Correia et al., 2006; Ono et al., 2008, Chaves et al., 2010), thus corroborating the results presented in this work.

The present study shows that $T$. angustula honey has high levels of phenolics and flavonoids and that the distribution of these compounds is influenced by the floral origin of the analyzed honey. Analysis by HPLC-DAD showed that the extracts are rich in phenolic acids, such as ferulic acid. NMR analysis showed signs of citric acid, succinic acid, proline and hydrocarbon derivatives and the presence of phenolic acid and flavonoids, in addition to carbohydrates. Finally, the total antioxidant capacity of honey is probably the result of the combined activities and interactions of a wide range of compounds, including amino acids, enzymes and possibly other minor components. However,

Table 3. Pollen type of the honey produced by Tetragonisca angustula from Vera Cruz, Itaparica Island, Bahia, NE, Brazil.

\begin{tabular}{|c|c|c|c|}
\hline Family & Pollen Type & Frequency (\%) & Frequency Class \\
\hline \multirow[t]{2}{*}{ Anacardiaceae } & Tapirira & 42.60 & PP \\
\hline & Schinus & 25.70 & SP \\
\hline Arecaceae & Cocos nucifera & 0.30 & MP \\
\hline Asteraceae & Emilia & 0.50 & MP \\
\hline \multirow[t]{2}{*}{ Euphorbiaceae } & Euphorbia & 5.30 & IMP \\
\hline & Acalypha & 6.70 & IMP \\
\hline \multirow[t]{3}{*}{ Fabaceae } & Senna & 1.00 & MP \\
\hline & Dalbergia & 1.00 & MP \\
\hline & Leucaena & 0.20 & MP \\
\hline Loranthaceae & Struthanthus & 0.10 & MP \\
\hline Malvaceae & Waltheria & 0.10 & MP \\
\hline Melastomataceae & Tibouchina & 5.80 & IMP \\
\hline \multirow[t]{2}{*}{ Myrtaceae } & Myrcia & 0.60 & MP \\
\hline & Eucalyptus & 0.40 & MP \\
\hline Poaceae & Tipo Poaceae & 1.30 & MP \\
\hline Rubiaceae & Borreria & 4.60 & IMP \\
\hline Sapindaceae & Serjania & 0.80 & MP \\
\hline Turneraceae & Turnera & 1.80 & MP \\
\hline Urticaceae & Cecropia & 1.20 & MP \\
\hline
\end{tabular}

Data represent analyses of 1.000 pollen grains $(n=1.000)$ counted in three different samples; standard deviation of means was $\leq 0.5$. $\mathrm{PP}=$ predominant pollen ( $>45 \%$ of total grains); $\mathrm{SP}=$ secondary pollen ( 16 to $45 \%$ ); IMP = important minor pollen ( 3 to $15 \%$ ); $\mathrm{MP}=$ minor pollen $(<3 \%)$ (Louveaux et al., 1978). 

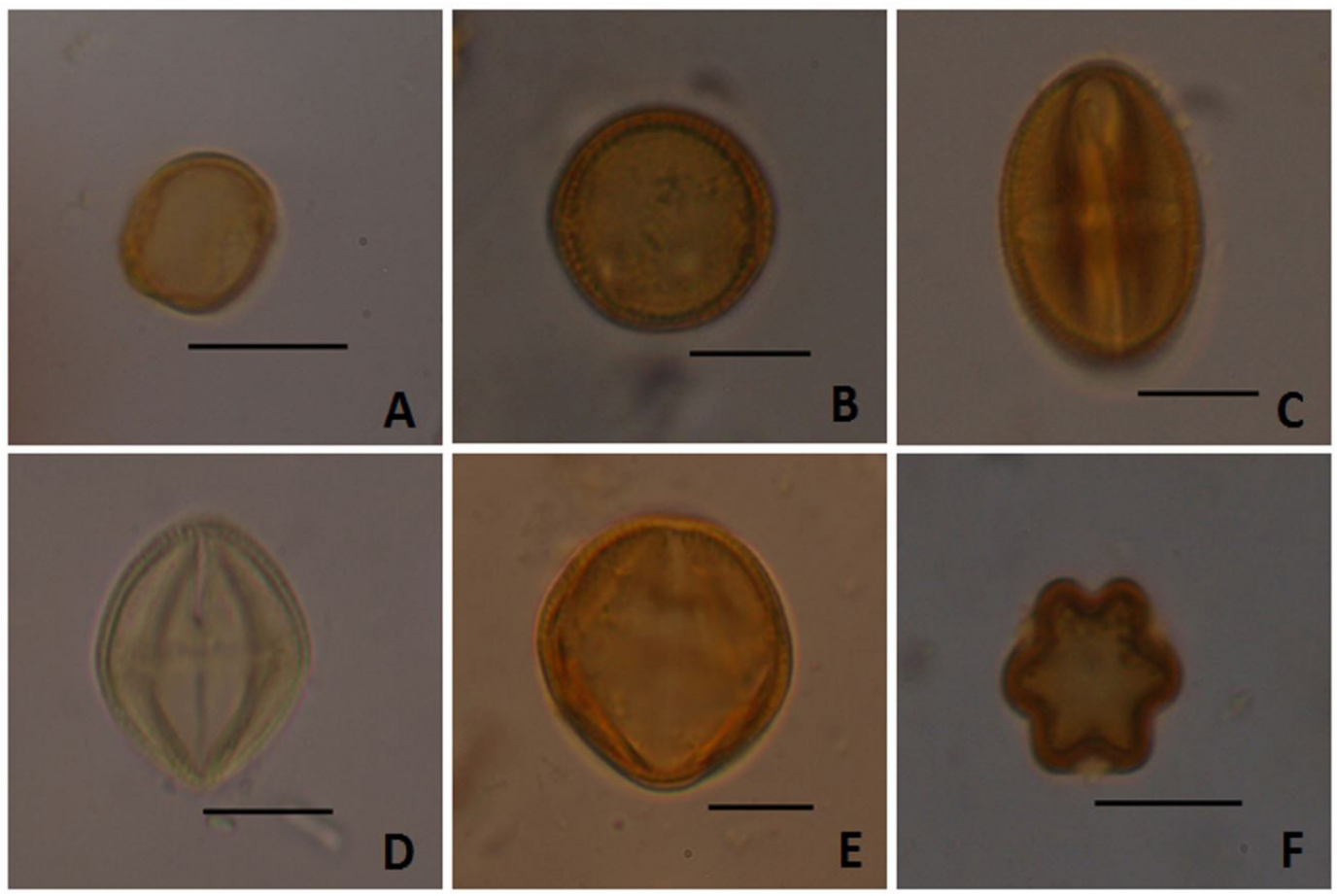

Figure 3. Photomicrography of pollen types of higher relative frequency in the pollen spectrum of the honey of Tetragonisca angustula from Vera Cruz, Itaparica Island, Bahia, Brazil. A- Acalypha, B- Borreria, C- Euphorbia, D- Schinus, E- Tapirira, F- Tibouchina. Scale: 10um.

phenolic compounds are well known for being the main contributors to this property, enriching the quality of honey as a functional food. Therefore, Tetragonisca angustula honey can be considered a natural source of antioxidants and can be added to the daily diet.

\section{Acknowledgements}

We thank teacher Abilio Borghi for the grammar review of the manuscript. This work was supported by to the Coordination of Improvement of Higher Education Personnel (CAPES, Brazil), Bahia State Research Support Foundation (FAPESB, Bahia, Brazil) and National Council for Scientific and Technological Development (CNPq, Brazil) for the grants and fellowship.

\section{References}

AL, M.L., DANIEL, D., MOISE, A., BOBIS, O., LASLO, L. and BOGDANOV, S., 2009. Physico-chemical and bioactive properties of different floral origin honeys from Romania. Food Chemistry, vol. 112 , no. 4, pp. 863-867. http://dx.doi.org/10.1016/j. foodchem.2008.06.055.

ALMEIDA, A.M.M., OLIVEIRA, M.B.S., COSTA, J.G., VALENTIM, I.B. and GOULART, M.O.F., 2016. Antioxidant capacity, physicochemical and floral characterization of honeys from the Northeast of Brazil. Revista Virtual Quimica, vol. 8, no. 1, pp. 57-77. http:// dx.doi.org/10.5935/1984-6835.20160005.

ALMEIDA-MURADIAN, L.B., STRAMM, K.M., HORITA, A., BARTH, O.M., FREITAS, A.S. and ESTEVINHO, L.M., 2013. Comparative study of the physicochemical and palynological characteristics of honey from Melipona subnitida and Apis mellifera. International Journal of Food Science E Technology, vol. 48, no. 8, pp. 16981706. http://dx.doi.org/10.1111/ijfs.12140.

ALVAREZ-SUAREZ, J.M., GIAMPIERI, F., GONZALEZ-PARAMAS, A.M., DAMIANI, E., ASTOLFI, P., MARTINEZ-SANCHEZ, G., BOMPADRE, S., QUILES, J.L., SANTOS-BUELGA, C. and BATTINO, M., 2012. Phenolics from monofloral honeys protect human erythrocyte membranes against oxidative damage. Food and Chemical Toxicology, vol. 50, no. 5, pp. 1508-1516. http://dx.doi. org/10.1016/j.fct.2012.01.042. PMid:22330201.

ATOUI, A.K., MANSOURI, A., BOSKOU, G. and KEFALAS, P., 2005. Tea and herbal infusions: their antioxidant activity and phenolic profile. Food Chemistry, vol. 89, no. 1, pp. 27-36. http://dx.doi. org/10.1016/j.foodchem.2004.01.075.

AYNA, A., ÖZBOLAT, S.N. and DARENDELIOGLU, E., 2020. Quercetin, chrysin, caffeic acid and ferulic acid ameliorate cyclophosphamide-induced toxicities in SH-SY5Y cells. Molecular Biology Reports, vol. 47, no. 11, pp. 8535-8543. http://dx.doi. org/10.1007/s11033-020-05896-4. PMid:33040267.

BARTOSZEK, M., POLAK, J. and CHORĄŻEWSKI, M., 2017. Comparison of antioxidant capacities of different types of tea using the spectroscopy methods and semi-empirical mathematical model. European Food Research and Technology, vol. 244, no. 4, pp. 595-601. http://dx.doi.org/10.1007/s00217-017-2986-z.

BERKER, K.I., GÜÇLÜ, K., TOR, I. and APAK, R., 2007. Comparative evaluation of $\mathrm{Fe}$ (III) reducing power-based antioxidant capacity assays in the presence of phenanthroline, batho-phenanthroline, tripyridyltriazine (FRAP), and ferricyanide reagents. Talanta, vol. 72, no. 3, pp. 1157-1165. http://dx.doi.org/10.1016/j. talanta.2007.01.019. PMid:19071739.

BERKER, K.I., OZDEMIR OLGUN, F.A., OZYURT, D., DEMIRATA, B. and APAK, R., 2013. Modified Folin-Ciocalteu antioxidant capacity assay for measuring lipophilic antioxidants. Journal of 
Agricultural and Food Chemistry, vol. 61, no. 20, pp. 4783-4791. http://dx.doi.org/10.1021/jf400249k. PMid:23627440.

BOBANY, D.M., PIMENTEL, M.A.P., MARTINS, R.R.C., NETTO, B.E.S. and TOLLA, M.S., 2010. Atividade antimicrobiana do mel de abelhas jataí (Tetragonisca angustula) em cultivo de microrganismos do conduto auditivo de caninos domésticos (Canis familiaris). Ciência Animal Brasileira, vol. 11, no. 2, pp. 441-446. http:// dx.doi.org/10.5216/cab.v11i2.4585.

CHAVES, M.H., ANTÔNIA MARIA DAS GRAÇAS LOPES, C., LOPES, J.A.D., COSTA, D.A., OLIVEIRA, C.A.A., COSTA, A.F. and BRITO JÚNIOR, F.E.M., 2010. Fenóis totais, atividade antioxidante e constituintes químicos de extratos de Anacardium occidentale L., Anacardiaceae. Revista Brasileira de Farmacognosia, vol. 20, no. 1, pp. 106-112. http://dx.doi.org/10.1590/S0102$695 \times 2010000100021$.

CHUA, L.S., RAHAMAN, N.L.A., ADNAN, N.A. and EDDIE TAN, T.T., 2013. Antioxidant activity of three honey samples in relation with their biochemical components. Journal of Analytical Methods in Chemistry, vol. 2013, pp. 313798. http://dx.doi. org/10.1155/2013/313798. PMid:24027653.

CIAPPINI, M.A., 2019. Polyhenolic profile of floral honeys in correlation with their pollen spectrum. Journal of Apicultural Research, vol. 58, no. 5, pp. 772-779. http://dx.doi.org/10.108 0/00218839.2019.1654967.

CONSONNI, R., BERNAREGGI, F. and CAGLIANI, L.R., 2019. NMRbased metabolomic approach to differentiate organic and conventional Italian honey. Food Control, vol. 98, pp. 133-140. http://dx.doi.org/10.1016/j.foodcont.2018.11.007.

CORREIA, S.J., DAVID, J.P. and DAVID, J.M., 2006. Metabólitos secundários de espécies de Anacardiaceae. Quimica Nova, vol. 29, no. 6, pp. 1287-1300. http://dx.doi.org/10.1590/S010040422006000600026.

COSTA, A.C.V.D., SOUSA, J.M.B., DA SILVA, M.A.A.P., GARRUTI, D.D.S. and MADRUGA, M.S., 2018. Sensory and volatile profiles of monofloral honeys produced by native stingless bees of the brazilian semiarid region. Food Research International, vol. 105, pp. 110-120. http://dx.doi.org/10.1016/j.foodres.2017.10.043. PMid:29433198.

DICASTILLO, C.L. DE, NAVARRO, R., GUARDA, A. and GALOTTO, M.J., 2015. Development of biocomposites with antioxidant activity based on red onion extract and acetate cellulose. Antioxidants (Basel), vol. 4, no. 3, pp. 533-547. https://doi.org/10.3390/ antiox4030533.

DONG, J.W., CAI, L., XING, Y., YU, J. and DING, Z.T., 2015. Re-evaluation of ABTS $^{*+}$ Assay for Total Antioxidant capacity of natural products. Natural Product Communications, vol. 10, no. 12, pp. 2169-2172. http://dx.doi.org/10.1177/1934578X1501001239. PMid:26882692.

DŻUGAN, M., SOWA, P., KWAŚNIEWSKA, M., WESOłOWSKA, M. and CZERNICKA, M., 2017. Physicochemical parameters and antioxidant activity of bee honey enriched with herbs. Plant Foods for Human Nutrition (Dordrecht, Netherlands), vol. 72, no. 1, pp. 74-81. http://dx.doi.org/10.1007/s11130-016-0593-y. PMid:28000091.

ERDTMAN, G., 1960. The acetolysis method. A revised description. Svensk Botanisk Tidskrift, vol. 54, pp. 561-564.

GRÜTER, C., KÄRCHER, M. and RATNIEKS, F., 2011. The Natural History of Nest Defence in a Stingless Bee, Tetragonisca angustula (Latreille) (Hymenoptera: Apidae), with Two Distinct Types of Entrance Guards. Neotropical Entomology, vol. 40, no. 1, pp. 55-61. http://dx.doi.org/10.1590/S1519-566X2011000100008. PMid:21437483.
KAMPA, M., ALEXAKI, V.I., NOTAS, G., NIFLI, A.P., NISTIKAKI, A., HATZOGLOU, A., BAKOGEORGOU, E., KOUIMTZOGLOU, E., BLEKAS, G., BOSKOU, D., GRAVANIS, A. and CASTANAS, E., 2004. Antiproliferative and apoptotic effects of selective phenolic acids on T47D human breast cancer cells: potential mechanisms of action. Breast Cancer Research, vol. 6, no. 2, pp. R63-R74. http:// dx.doi.org/10.1186/bcr752. PMid:14979919.

KORTESNIEMI, M., SLUPSKY, C.M., OLLIKKA, T., KAUKO, L., SPEVACEK, A.R., SJÖVALL, O., YANG, B. and KALLIO, H., 2016. NMR profiling clarifies the characterization of Finnish honeys of different botanical origins. Food Research International, vol. 86, pp. 83-92. http://dx.doi.org/10.1016/j.foodres.2016.05.014.

KOSAKA, A., AIDA, M. and KATSUMOTO, Y., 2015. Reconsidering the activation entropy for anomerization of glucose and mannose in water studied by NMR spectroscopy. Journal of Molecular Structure, vol. 1093, no. 5, pp. 195-200. http://dx.doi. org/10.1016/j.molstruc.2015.03.038.

LEE, D., LEE, O.H., CHOI, G. and KIM, J.D., 2017. Antioxidant and antiadipogenic activities of trapa japonica shell extract cultivated in Korea. Preventive Nutrition and Food Science, vol. 22, no. 4, pp. 327-334. http://dx.doi.org/10.3746/pnf.2017.22.4.327. PMid:29333386.

LI, H.Y., HAO, Z.B., WANG, X.L., HUANG, L. and LI, J.-P., 2009. Antioxidant activities of extracts and fractions from Lysimachia foenum-graecum Hance. Bioresource Technology, vol. 100, no. 2, pp. 970-974. http://dx.doi.org/10.1016/j.biortech.2008.07.021. PMid:18793841.

LIMA, A.C.D.O., CONCEICAO, R.S., FREITAS, L.S., CARVALHO, C.A.L., CONCEICAO, A.L.D.S., FREITAS, H.F., PITA, S.S.D.R., IFA, D.R., PINHEIRO, A.M., and BRANCO, A., 2021. Hydroxycinnamic acid-spermidine amides from Tetragonisca angustula honey as anti-Neospora caninum: In vitro and in silico studies. Chemical Biology \& Drug Design, vol. 98, no. 6, pp. 1104-1115. https:// doi.org/10.1111/cbdd.13969.

LOUVEAUX, J., MAURIZIO, A. and VORWOHL, G., 1978. Methods of Melissopalynology. Bee World, vol. 59, no. 4, pp. 139-157. http:// dx.doi.org/10.1080/0005772X.1978.11097714.

MEDA, A., LAMIEN, C.E., ROMITO, M., MILLOGO, J. and NACOULMA, O.G., 2005. Determination of the total phenolic, flavonoid and proline contents in Burkina Fasan honey, as well as their radical scavenging activity. Food Chemistry, vol. 91, no. 3, pp. 571-577. http://dx.doi.org/10.1016/j.foodchem.2004.10.006.

MONIRUZZAMAN, M., AN, C.Y., RAO, P.V., HAWLADER, M.N.I., AZLAN, S.A.B.M., SULAIMAN, S.A. and GAN, S.H., 2014. Identification of phenolic acids and flavonoids in monofloral honey from Bangladesh by high performance liquid chromatography: determination of antioxidant capacity. BioMed Research International, vol. 2014, pp. 1-11. https://doi. org/10.1155/2014/737490.

NASCIMENTO, A., MARCHINI, L., CARVALHO, C., ARAÚJO, D., OLINDA, R. and SILVEIRA, T., 2015. Physical chemical parameters of honey of stingless bee (Hymenoptera: apidae). American Chemical Science Journal, vol. 7, no. 3, pp. 139-149. http://dx.doi. org/10.9734/ACSJ/2015/17547.

NISHIO, E.K., RIBEIRO, J.M., OLIVEIRA, A.G., ANDRADE, C.G.T.J., PRONI, E.A., KOBAYASHI, R.K.T. and NAKAZATO, G., 2016. Antibacterial synergic effect of honey from two stingless bees: Scaptotrigona bipunctata Lepeletier, 1836, and S. postica Latreille, 1807. Scientific Reports, vol. 6, no. 21641, pp. 21641. http://dx.doi.org/10.1038/ srep21641. PMid:26869239.

NOVAIS, J.S., ABSY, M.L. and SANTOS, F.A.R., 2013. Pollen grains in honeys produced by Tetragonisca angustula (Latreille, 1811) (Hymenoptera: Apidae) in tropical semi-arid areas of north- 
eastern Brazil. Arthropod-Plant Interactions, vol. 7, no. 6, pp. 619-632. http://dx.doi.org/10.1007/s11829-013-9276-x.

NOVAIS, J.S., GARCÊZ, A.C.A., ABSY, M.L. and SANTOS, F.A.R., 2014. Comparative pollen spectra of Tetragonisca angustula (Apidae, Meliponini) from the Lower Amazon (N Brazil) and caatinga (NE Brazil).Apidologie, vol. 46, no. 4, pp. 417-431. http://dx.doi. org/10.1007/s13592-014-0332-z.

ODDO, L.P., HEARD, T.A., RODRIGUEZ-MALAVER, A., PÉREZ, R.A., FERNANDEZ-MUIÑO, M., SANCHO, M.T., SESTA, G., LUSCO, L. and VIT, P., 2008. Composition and antioxidant activity of trigona carbonaria honey from Australia. Journal of Medicinal Food, vol. 11, no. 4, pp. 789-794. http://dx.doi.org/10.1089/ jmf.2007.0724. PMid:19012514.

ONO, M., YAMASHITA, M., MORI, K., MASUOKA, C., ETO, M., KINJO, J., IKEDA, T., YOSHIMITSU, H. and NOHARA, T., 2008. Serquiterpenoids, triterpenoids and flavonoids from the fruits of Schinus molle. Food Science and Technology Research, vol. 14, no. 5, pp. 499-508. http://dx.doi.org/10.3136/fstr.14.499.

ORŠOLIĆ, N. and CAR, N., 2014. Quercetin and hyperthermia modulate cisplatin-induced DNA damage in tumor and normal tissues in vivo. Tumour Biology, vol. 35, no. 7, pp. 6445-6454. http://dx.doi.org/10.1007/s13277-014-1843-y. PMid:24682902.

PAIVA, L.B., GOLDBECK, R., SANTOS, W.D. and SQUINA, F.M., 2013. Ferulic acid and derivatives: molecules with potential application in the pharmaceutical field. Brazilian Journal of Pharmaceutical Sciences, vol. 49, no. 3, pp. 395-411. http://dx.doi.org/10.1590/ S1984-82502013000300002.

PALYNOLOGICAL DATABASE [online], 2018 [viewed 10 February 2020]. Available from: https://www.paldat.org/info

PARDO-ANDREU, G.L., SÁNCHEZ-BALDOQUÍN, C., ÁVILA-GONZÁLEZ, R., DELGADO, R., NAAL, Z. and CURTI, C., 2006. Fe(III) improves antioxidant and cytoprotecting activities of mangiferin. European Journal of Pharmacology, vol. 547, no. 1-3, pp. 31-36. http:// dx.doi.org/10.1016/j.ejphar.2006.07.040. PMid:16945365.

POLAK, J. and BARTOSZEK, M., 2015. The study of antioxidant capacity of varieties of nalewka, a traditional Polish fruit liqueur, using EPR, NMR and UV-vis spectroscopy. Journal of Food Composition and Analysis, vol. 40, pp. 114-119. http:// dx.doi.org/10.1016/j.jfca.2015.01.006.

R CORE TEAM, 2020 [viewed 10 February 2020]. Hidro web: R: A language and environment for statistical computing [online]. Vienna, Austria: R Foundation for Statistical Computing. Available from: http://www.r-project.org/index.html

RAO, P.V., KRISHNAN, K.T., SALLEH, N. and GAN, S.H., 2016. Biological and therapeutic effects of honey produced by honey bees and stingless bees: a comparative review. Revista Brasileira de Farmacognosia, vol. 26, no. 5, pp. 657-664. http://dx.doi. org/10.1016/j.bjp.2016.01.012.

RODRÍGUEZ-MALAVER, A.J., RASMUSSEN, C., GUTIÉRREZ, M.G., GIL, F., NIEVES, B. and VIT, P., 2009. Properties of honey from tem species of Peruvian stingless bees. Natural Product Communications, vol. 4, no. 9, pp. 1221-1226. http://dx.doi. org/10.1177/1934578X0900400913. PMid:19831033.

SALGUEIRO, F.B., LIRA, A.L., RUMJANEK, V. and CASTRO, R.N., 2016. Botanical characterization of brazilian honeys by nuclear magnetic resonance spectroscopy and chemometrics. Revista Virtual de Química, vol. 8, no. 1, pp. 277-287. http://dx.doi. org/10.5935/1984-6835.20160018.

SANT'ANA, L.D.O., SOUSA, J.P.L.M., SALGUEIRO, F.B.F.B., LORENZON, M.C.A. and CASTRO, R.N., 2012. Characterization of monofloral honeys with multivariate analysis of their chemical profile and antioxidant activity. Journal of Food Science, vol. 77, no. 1, pp. C135-140. http://dx.doi.org/10.1111/j.1750-3841.2011.02490.x. PMid:22133147.
SGARIGLIA, M.A., VATTUONE, M.A., SAMPIETRO VATTUONE, M.M., SOBERÓN, J.R. and SAMPIETRO, D.A., 2010. Properties of honey from Tetragonisca angustula fiebrigi and Plebeia wittmanni of Argentina. Apidologie, vol. 41, no. 6, pp.667-675. http://dx.doi. org/10.1051/apido/2010028.

SIESS, M.-H., LE BON, A.-M., CANIVENC-LAVIER, M.-C., AMIOT, M.-J., SABATIER, S., AUBERT, S.Y. and SUSCHETET, M., 1996. Flavonoids of Honey and Propolis: Characterization and Effects on Hepatic Drug-Metabolizing Enzymes and Benzo[a] pyrene-DNA Binding in Rats. Journal of Agricultural and Food Chemistry, vol. 44, no. 8, pp. 2297-2301. http://dx.doi. org/10.1021/jf9504733.

SILVA, I.A., DA SILVA, T.M., CAMARA, C.A., QUEIROZ, N., MAGNANI, M., DE NOVAIS, J.S., SOLEDADE, L.E., LIMA, E.O., DE SOUZA, A.L. and DE SOUZA, A.G., 2013a. Phenolic profile, antioxidant activity and palynological analysis of stingless bee honey from Amazonas, Northern Brazil. Food Chemistry, vol. 141, no. 4, pp. 3552-3558. http://dx.doi.org/10.1016/j.foodchem.2013.06.072. PMid:23993520.

SILVA, T.M.S., DOS SANTOS, F.P., EVANGELISTA-RODRIGUES, A., DA SILVA, E.M.S., DA SILVA, G.S., DE NOVAIS, J.S., DOS SANTOS, F.A.R. and CAMARA, C.A., 2013b. Phenolic compounds, melissopalynological: physicochemical analysis and antioxidant activity of jandaıra (Meliponasubnitida) honey. Journal of Food Composition and Analysis, vol. 29, no. 1, pp. 10-18. http://dx.doi. org/10.1016/j.jfca.2012.08.010.

SINGLETON, V.L., ORTHOFER, R. and LAMUELA-RAVENTÓS, R.M., 1999. Analysis of total phenols and other oxidation substrates and antioxidants by means of folin-ciocalteu reagent. Methods in Enzymology, vol. 299, pp. 152-178. http://dx.doi.org/10.1016/ S0076-6879(99)99017-1.

SPITERI, M., JAMIN, E., THOMAS, F., REBOURS, A., LEES, M., ROGERS, K.M. and RUTLEDGE, D.N., 2015. Fast and global authenticity screening of honey using ${ }^{1} \mathrm{H}-\mathrm{NMR}$ profiling. Food Chemistry, vol. 189, no. 15, pp. 60-66. http://dx.doi.org/10.1016/j. foodchem.2014.11.099. PMid:26190601.

TOMAS-BARBERAN, F.A., MARTOS, I., FERRERES, F., RADOVIC, B.S. and ANKLAM, E., 2001. HPLC flavonoid profiles as markers for the botanical origin of European unifloral honeys. Journal of the Science of Food and Agriculture, vol. 81, no. 5, pp. 485-496. http://dx.doi.org/10.1002/jsfa.836.

TRUSHEVA, B., TRUNKOVA, D. and BANKOVA, V., 2007. Different extraction methods of biologically active components from propolis: a preliminary study. Chemistry Central Journal, vol. 1, pp. 13. http://dx.doi.org/10.1186/1752-153X-1-13. PMid:17880743.

TUKSITHA, L., CHEN, Y.-L.S., CHEN, Y.-L., WONG, K.-Y. and PENG, C.-C., 2018. Antioxidant and antibacterial capacity of stingless bee honey from Borneo (Sarawak). Journal of AsiaPacific Entomology, vol. 21, no. 2, pp. 563-570. http://dx.doi. org/10.1016/j.aspen.2018.03.007.

VON DER OHE, W., PERSANO ODDO, L., PIANA, M.L., MORLOT, M. and MARTIN, P., 2004. Harmonized methods of melissopalynology. Apidologie, vol. 35, suppl. 1, pp. S18-S25. http://dx.doi. org/10.1051/apido:2004050.

WANG, S.Y. and LIN, H.S., 2000. Antioxidant activity in fruits and leaves of blackberry, raspberry, and strawberry varies with cultivar and developmental stage. Journal of Agricultural and Food Chemistry, vol. 48, no. 2, pp. 140-146. http://dx.doi. org/10.1021/jf9908345. PMid:10691606.

WOISKY, R.G. and SALATINO, A., 1998. Analysis of propolis: some parameters and procedures for chemical quality control.Journal of Agricultural Research, vol. 37, no. 2, pp. 99-105. http://dx.doi. org/10.1080/00218839.1998.11100961. 